\title{
JOHN ALEXANDER
}

In the death of John Alexander, of Ann Arbor, U.S.A., thoracic surgery has suffered a great loss. He died in July, ironically enough from a condition quite unrelated to the disease which had been a constant companion and burden to him for more than a quarter of a century.

No one meeting him would know, except by previous knowledge, that he suffered from tuberculosis, and certainly only if one were intimate with him would the slightest hint be given that such was the case.

$\mathrm{His}$ disease was widespread, involving the spinal column, the genito-urinary tract, and the lungs. The first edition of his book was written when he was lying on his back with spinal caries, using a

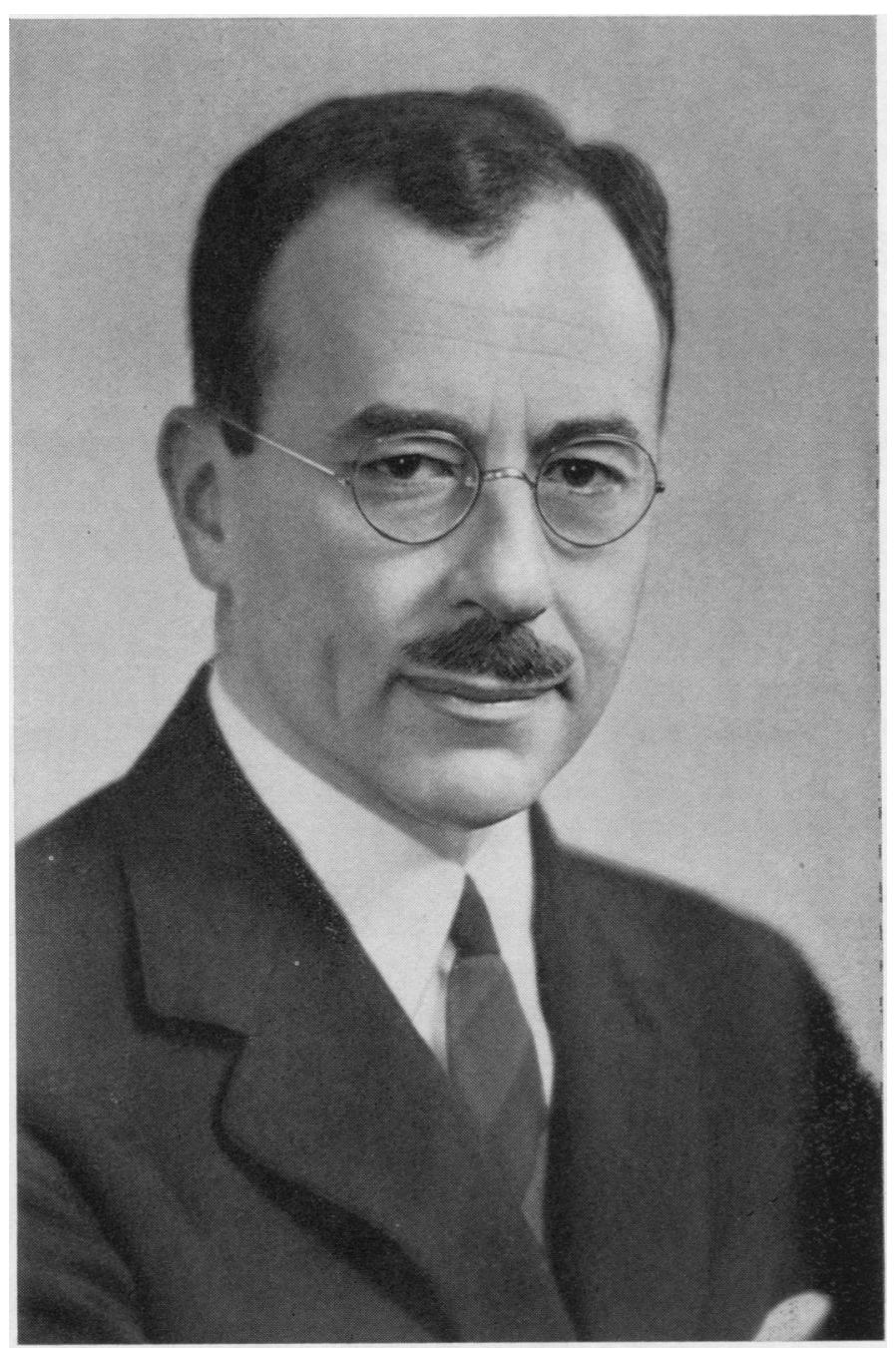

Despite all this, he gathered around him a school of young surgeons and physicians, who will continue to bear and pass on the impress of John Alexander. He radiated friendliness; his entry into a room was immediately remarked, and he filled the room, as it were, with a rich fragrance.

At each meeting of the American Association for Thoracic Surgery at which he was present, and it was rare for him to miss these meetings, his " "boys" gave him a luncheon party. It was an inspiring sight to see these 40 or so surgeons, distinguished in their own right, doing honour and paying tribute to their Chief, a tribute he accepted as modestly as a father does that of his own family.

It is a remarkperiscopic mirror for the purpose. During the latter years of his life one kidney had practically ceased to function, and the other had a ureterostomy. 
country, and for those of us who were privileged to meet him he certainly equally inspired our affection.

He was truly a great man, with all a great man's qualities - courage, unbounded cheerfulness in all circumstances, the ability to command an unfailing loyalty in all those who came within the sphere of his influence, the faculty for hard work and application, and withal a breadth of vision sufficient to see what is important and the ability to communicate $h$ views to others.

His contribution to the surgery of tuberculos will long be remembered, but it is doubtful whether it will be remembered for a longer time than will be his courage, great humanity, and his devotion to his self-appointed task.

American thoracic surgeons will miss his wis counsel and encouragement, and we, in this. country, will share their loss. $\quad$ C. P. T. $\stackrel{\omega}{\omega}$ 